\title{
ANALISIS TENTANG PENDIDIKAN DAN PELATIHAN TERHADAP PENINGKATAN KOMPETENSI PEGAWAI NEGERI SIPIL DALAM MENGHADAPI MASYARAKAT EKONOMI ASEAN (MEA)
}

\author{
Tanti Kirana Utami \\ Dosen Fakultas Hukum Universitas Suryakancana \& Mahasiswa Doktoral \\ Pascasarjana Universitas Islam Bandung (UNISBA)
}

\begin{abstract}
ABSTRAK
Masyarakat Ekonomi Asean (MEA)/AEC (Asean Economic Community) 2015 adalah program yang telah lama disiapkan seluruh anggota ASEAN yang bertujuan untuk meningkatkan stabilitas perekonomian di kawasan ASEAN dan membentuk kawasan ekonomi antar negara ASEAN yang kuat. Salah satu aspek penting yang perlu disiapkan dengan cepat bangsa ini adalah SDM pegawai negeri sipil yang kompeten. Program peningkatan kompetensi pegawai dilakukan melalui program pendidikan dan pelatihan pelatihan. Pendidikan dan pelatihan pegawai memberi kontribusi pada peningkatan produktivitas, efektitas dan efisiensi organisasi.
\end{abstract}

Kata Kunci: Peningkatan Kompetensi, Pegawai Negeri Sipil, Masyarakat Ekonomi Asean.

\begin{abstract}
ABSTRAC
Asean Economic Community (AEC) / AEC (Asean Economic Community) in 2015 is a program that has long been prepared all members of ASEAN which aims to improve the economic stability in the ASEAN region and form the economic area among ASEAN countries is strong. One important aspect that needs to be prepared quickly this nation is the human resources competent civil servants. The program to improve the competence of employees is done through education and training programs training. Education and training of personnel contributed to the increase in productivity, efektitas and organizational efficiency.
\end{abstract}

Keywords: Competency Enhancement, Civil Servants, the Asean Economic Community.

\section{PENDAHULUAN.}

Masyarakat Ekonomi ASEAN (MEA) merupakan bentuk integrasie Ekonomi yang sangat potensial di kawasan Asia maupun dunia. Barang, jasa, modal dan investasi akan bergerak bebas di kawasan ini. Hal ini menyiratkan aspek persaingan yang memberikan peluang sekaligus tantangan bagi semua negara. 
Indonesia mempunyai kekuatan ekonomi yang cukup bagus, pertumbuhan ekonomi tertinggi di dunia (4,5\% data BPS, tahun 2009) setelah RRT dan India. Ini akan menjadi modal yang penting untuk mempersiapkan masyarakat Indonesia menuju ASEAN Economic Community (AEC) atau Masyarakat Ekonomi ASEAN (MEA) tahun 2015.

Masyarakat Ekonomi Asean (MEA)/AEC (Asean Economic Community) 2015 adalah program yang telah lama disiapkan seluruh anggota ASEAN yang bertujuan untuk meningkatkan stabilitas perekonomian di kawasan ASEAN dan membentuk kawasan ekonomi antar negara ASEAN yang kuat. Dengan diberlakukannya MEA pada akhir Tahun 2015, negara anggota ASEAN akan mengalami aliran bebas barang, jasa, investasi, dan tenaga kerja terdidik dari dan ke masing-masing negara. Dalam hal ini, yang perlu dilakukan oleh Indonesia adalah bagaimana Indonesia sebagai bagian dari komunitas ASEAN berusaha untuk mempersiapkan kualitas diri dan memanfaatkan peluang MEA 2015, serta harus meningkatkan kompetensi untuk dapat bersaing dengan Negara anggota ASEAN lainnya.

Postur birokrasi Indonesia masih menghadapi tantangan berat dalam menghadapi Masyarakat Ekonomi ASEAN (MEA) yang telah berjalan sejak awal tahun 2016 lalu. Postur birokrasi di Indonesia sesungguhnya berada dalam posisi yang kurang baik. Hal tersebut dikarenakan dari total 4,49 juta Pegawai Negeri Sipil (PNS), sebanyak 44 persen masih lulusan Sekolah Menengah Atas (SMA)."Sebanyak 44 persen merupakan lulusan SMA, SMP bahkan SD, itu hampir separuhnya. Sementara untuk S1 sebanyak 42 persen, S2 sebanyak 12 persen dan S3 baru 1,1 persen,"1

Postur birokrasi yang ada saat ini, untuk bersaing khususnya dalam MEA menjadi pekerjaan yang sangat berat. Dengan kondisi tersebut, diperlukan strategi yang baik dan upaya yang besar dari pemerintah agar para PNS tersebut bisa meningkatkan kapasitas dan kompetensi sesuai dengan kebutuhan masing-masing.

1 LAN,http://economy.okezone.com/read/2016/04/07/320/1356886/postur-birokrasiindonesia- hadapi-tantangan-mea, diunduh pada hari Rabu, 30 maret 2016, pukul 12.00 WIB.

Vol. II No. 01 Edisi Januari-Juni 2016. 
Pada beberapa wilayah di Indonesia memang sudah ada berbagai bentuk pelatihan terhadap aparatur negara tersebut. Namun tidak semua wilayah memiliki program tersebut, terlebih saat ini, para PNS itu masih dianggap sebagai faktor produksi dan bukan aset Negara.

Salah satu aspek penting yang perlu disiapkan dengan cepat bangsa ini adalah SDM yang kompeten. Kualitas sumber daya manusia merupakan faktor penentu keberhasilan pembangunan dan kemajuan suatu bangsa. Untuk itu, penulis akan mengkaji permasalahan ini dengan membatasi pada hal-hal mengenai penerapan sistem merit dalam manajemen pegawai negeri sipil dan peningkatan kompetensi pegawai negeri sipil melalui pendidikan dan pelatihan dalam menghadapi MEA.

\section{PEMBAHASAN.}

\section{A. Manajemen Pegawai Negeri Sipil.}

Tujuan nasional seperti tercantum dalam Pembukaan UUD 1945 adalah melindungi segenap bangsa Indonesia dan seluruh tumpah darah Indonesia, memajukan kesejahteraan umum, mencerdaskan kehidupan bangsa, dan ikut melaksanakan ketertiban dunia yang berdasarkan kemerdekaan, perdamaian abadi, dan keadilan sosial. ${ }^{2}$

Dalam rangka mencapai tujuan nasional sebagaimana tercantum dalam alinea ke-4 Pembukaan Undang-Undang Dasar Negara Republik Indonesia Tahun 1945 (UUD 1945), diperlukan Aparatur Sipil Nasional yang profesional, bebas dari intervensi politik, bersih dari praktik korupsi, kolusi, dan nepotisme, mampu menyelenggarakan pelayanan publik bagi masyarakat dan mampu menjalankan peran sebagai perekat persatuan dan kesatuan bangsa berdasarkan Pancasila dan UUD 1945.

Untuk mewujudkan tujuan nasional, dibutuhkan Pegawai Aparatur Sipil Nasional. Salah satu Pegawai Aparatur Sipil Nasional adalah pegawai negeri sipil yang diberikan tugas untuk melaksanakan tugas pelayanan publik, tugas pemerintahan, dan tugas pembangunan tertentu.

\footnotetext{
2 Penjelasan Umum UU nomor 5 Tahun 2014 tentang Aparatur Sipil Nasional.
} 
Untuk membentuk pegawai negeri sipil yang mampu menyelenggarakan pelayanan publik dan menjalankan peran sebagai perekat persatuan dan kesatuan Negara Kesatuan Republik Indonesia dibuatlah Undang-Undang nomor 5 Tahun 2014 tentang Aparatur Sipil Nasional.

Salah satu aspek penting yang perlu disiapkan dengan cepat bangsa Indonesia adalah SDM yang kompeten. Kualitas sumber daya manusia merupakan faktor penentu keberhasilan pembangunan dan kemajuan suatu bangsa. Oleh karena itu, diperlukan perubahan system dalam manajemen pegawai negeri sipil.

Manajemen dalam konsep populernya berarti suatu upaya atau proses upaya seorang pimpinan dengan satu kewenangan tertentu untuk mewujudkan sesuatu tujuan tertentu dengan memanfaatkan berbagai sumber daya yang ada dan yang sudah dikuasai pimpinan itu, terutama sumber daya manusia yang berada di bawah kekuasaannya. ${ }^{3}$

Manajemen Pegawai Negeri Sipil perlu diatur secara menyeluruh, dengan menerapkan norma, standar dan prosedur yang seragam dalam penetapan formasi, pengadaan, pengembangan, penetapan gaji, dan program kesejahteraan, serta pemberhentian yang merupakan unsur dalam manajemen Pegawai Negeri Sipil yang seragam di seluruh Indonesia. Hal ini dilakukan sejalan dengan strategi pelaksanaan reformasi birokrasi di Indonesia.

Birokrasi yang dalam bahasa inggris disebut bureaucracy berasal dari kata bureau (berarti meja) dan cratein ( berarti kekuasaan), maksudnya kekuasaan berada pada orang-orang yang dibelakang meja. Di Indonesia, birokrasi cenderung diartikan berbelit-belit. Kendati sebenarnya bila orang-orang yang dibelakang meja itu disiplin, terampil, taat pada tugas, dan tidak membedakan orang, maka hal yang dikhawatirkan tersebut diatas tidak akan terjadi. ${ }^{4}$

Manajemen pegawai negeri sipil adalah pengelolaan pegawai negeri sipil untuk menghasilkan Pegawai ASN yang profesional, memiliki nilai dasar, etika profesi, bebas dari intervensi politik, bersih dari praktik korupsi, kolusi, dan

3 Buchari Zainun, Manajemen dan Motivasi, Ghalia, Jakarta, 1986, hlm. 41.

4 Inu Kencana Syafiie, Sistem Administrasi Negara Republik Indonesia (SANRI), CEt ketiga, Bimi Aksara, Jakarta, 2008, hlm. 110. 
nepotisme. Tujuan utama undang-undang nomor 5 Tahun 2014 tentang ASN adalah sebagai berikut:

1. Independen dan Netralitas;

2. Kompetensi;

3. Kinerja/ Produktivitas Kerja;

4. Integritas

5. Kesejahteraan

6. Kualitas Pelayanan Publik

7. Pengawasan \& Akuntabilitas

Perubahan kebijakan SDM menurut Undang-Undang Nomor 5 tahun 2014 tentang Aparatur Sipil nasional adalah:

1. Karier ditentukan berdasarkan komitmen terhadap kinerja bukan hanya kedudukan;

2. Pangkat melekat pada jabatan bukan pada orang;

3. Remunerasi ditentukan pada kinerja bukan semata pada Jabatan saja;

4. Kedudukan dalam jabatan didasarkan pada:

a. Standar Kompetensi

b. Pengembangan Kompetensi bagi PNS \& PPPK dalam rangka meningkatkan Profesionalisme.

c. Pembatasan masa jabatan (5 Tahun);

d. Rekruitmen terbuka untuk JPT;

e. ASN dinamis mengikuti tupoksi yang dinamis.

Pegawai Negeri Sipil yang selanjutnya disingkat PNS adalah warga negara Indonesia yang memenuhi syarat tertentu, diangkat sebagai Pegawai ASN secara tetap oleh pejabat pembina kepegawaian untuk menduduki jabatan pemerintahan.

Di dalam Pasal 2 Undang-Undang nomor 5 Tahun 2014 tentang ASN Penyelenggaraan kebijakan dan Manajemen pegawai negeri sipil berdasarkan pada asas:

1. Kepastian hukum;

2. Profesionalitas;

3. Proporsionalitas; 
4. Keterpaduan;

5. Delegasi;

6. Netralitas;

7. Akuntabilitas;

8. Efektif dan efisien;

9. Keterbukaan;

10. Nondiskriminatif;

11. Persatuan dan kesatuan;

12. Keadilan dan kesetaraan; dan

13. Kesejahteraan.

Selanjutnya, dalam Pasal 3 Undang-Undang nomor 5 Tahun 2014 tentang ASN dijelaskan bahwa Pegawai negeri sipil sebagai profesi berlandaskan pada prinsip sebagai berikut:

1. Nilai dasar;

2. Kode etik dan kode perilaku;

3. Komitmen, integritas moral, dan tanggung jawab pada pelayanan publik;

4. Kompetensi yang diperlukan sesuai dengan bidang tugas;

5. Kualifikasi akademik;

6. Jaminan perlindungan hukum dalam melaksanakan tugas; dan

7. Profesionalitas jabatan.

Fungsi pegawai negeri sipil adalah:

1. pelaksana kebijakan publik;

2. pelayan publik; dan

3. perekat dan pemersatu bangsa

Adapun status pegawai negeri sipil adalah:

1. Berstatus pegawai tetap;

2. Memiliki NIP secara nasional;

3. Sebagai pembuat kebijakan;

4. Dapat menduduki jabatan pimpinan tinggi pemerintahan.

Peran pegawai negeri sipil adalah: Sebagai perencana, pelaksana, dan pengawas: 
1. Penyelenggaraan tugas umum pemerintahan

2. Pelaksana pembangunan nasional melalui yanlik yang profesional,

3. Bebas dari intervensi politik,

4. Bersih dari praktik kkn (korupsi, kolusi, dan nepotisme).

Prinsip dasar dalam undang-undang aparatur sipil negara adalah memberlakukan system merit yaitu:

1. Seleksi/promosi dilakukan secara adil dan kompetitif;

2. Menerapkan prinsip fairness;

3. Pemberian gaji, reward, and punishment berbasis pada kinerja;

4. Menerapkan Standar integritas dan perilaku pada Yanlik;

5. Manajemen SDM dilakukan secara efektif dan efisien;

6. Melindungi pegawai dari intervensi politik dan dari tindakan pejabat/penguasa yang semena-mena.

Sistem Merit adalah kebijakan Manajemen ASN yang diterapkan berdasarkan pada kualifikasi, kompetensi, dan kinerja secara adil, wajar, tanpa membedakan latar belakang: baik secara politik, ras, warna kulit, agama, asal usul, jenis kelamin, status pernikahan, umur, ataupun kondisi kecacatan.

Pengaturan manajemen pegawai negeri sipil mengalami beberapa perubahan, semula yang menjadi dasar hukumnya adalah UU nomor 8 Tahun 1974 tentang pokok-pokok kepegawaian yang diubah dengan UU no. 43 tahun 1999 yang mengatur PNS, kemudian diganti dengan UU nomor 5 Tahun 2014 tentang ASN mengatur PNS dan PPPK.

Penerapan konsep tata kelola pemerintahan yang baik (good governance) tanpa disertai dengan upaya peningkatan kapasitas dan kapabilitas aparatur penyelenggara pemerintahan tentunya tidak akan banyak mengubah wajah penyelenggaraan pemerintahan kita. Dalam arti bahwa harapan masyarakat akan terlaksananya peran dan fungsi serta tugas pemerintahan secara optimal tetap akan jauh dari apa yang seharusnya dilakukan sehingga dapat memenuhi aspirasi dan kepentingan serta kebutuhan warga masyarakat.

Pada era reformasi ini, upaya untuk mewujudkan sistem pemerintahan yang demokratis, bersih, dan berwibawa telah menjadi prioritas utama bagi rakyat 
dan pemerintahan Indonesia. Salah satu upaya reformasi itu adalah penataan aparatur pemerintah. ${ }^{5}$

Manajemen SDM berbasis kompetensi, dapat diuraikan dalam setiap keputusan dan kegiatannya harus transparan, dapat dipertanggungjawabkan secara ilmiah dan tidak diskriminatif. Hal ini karena mengacu pada kebutuhan kompetensi jabatan dan individu yang terukur dan dapat diamati validitasnya berdasarkan perilaku seseorang yang bekerja dalam suatu organisasi. Oleh karena itu, sistem ini pun dikenal sebagai manajemen SDM berbasis kompetensi yang terpadu.

\section{B. Peningkatan Kompetensi Pegawai Negeri Sipil.}

Salah satu bentuk program pengembangan pegawai dilakukan melalui program pendidikan dan pelatihan pelatihan. Pendidikan dan pelatihan pegawai memberi kontribusi pada peningkatan produktivitas, efektitas dan efisiensi organisasi.Pendidikan dan pelatihan bagi pegawai harus diberikan secara berkala agar setiap pegawai terpelihara kompetensinya untuk peningkatan kinerja organisasi. Oleh karena ini program pelatihan harus mendapat perhatian melalui perencanaan kebutuhan diklat bagi setiap pegawai. ${ }^{6}$

Pelatihan dimaksudkan untuk meningkatkan keterampilan pegawai baik secara horizontal maupun vertical. Secara horizontal berarti memperluas keterampilan jenis pekerjaan yang diketahui, sedangkan vertical memperdalam satu bidang tertentu. ${ }^{7}$

Pengembangan karir yang dilaksanakan dan dikembangkan pada SDM aparatur (PNS) melalui pembinaan karir dan penilaian sistem prestasi kerja. Sistem karir pada umumnya melalui kenaikan pangkat, mutasi jabatan serta promosi (pengangkatan ke jabatan lain). Lebih lanjut Moekijat (1995) mengatakan

5 Sri Hartini, dkk, Hukum Kepegawaian di Indonesia, Jakarta, 2010, hlm. 5.

6 Firdaus Hafid,Pengembangan Kompetensi PNS Melalui Pendidikan dan Pelatihan, http://makassar.lan.go.id/index.php/survei/publikasi/artikel/269-pengembangankompetensi-pegawai-negeri-sipil-melalui-pendidikan-dan-pelatihan, diunduh pada hari Selasa tanggal 5 April 2016, pukul 12.00 WIB.

7 Simanjuntak, Pengantar Ekonomi Sumber Daya Manusia, Lembaga Penerbit FE-UI, Jakarta,1985, hlm. 58. 
bahwa : dalam pengembangan karir seharusnya diterima bukan sekedar promosi ke jabatan yang lebih tinggi, tetapi sukses karir yang dmaksudkan seorang karyawan mengalami kemajuan dalam bekerja, berupa kepuasan dalam jabatan yang dipercayakan serta meningkatkan ketrampilan. Hal yang penting dalam pengembangan karir adalah: (1) ada kesempatan untuk melakukan yang menyenangkan; (2) Kesempatan untuk mencapai sesuatu yang berharga; (3) Kesempatan untuk mempelajari hal-hal yang baru; (4) kesempatan untuk mengembangkan kecakapan kemampuan. ${ }^{8}$

Menurut Smith; training is a planned process to modify attitude, knowledge, skill behavior through learning experience to achieve effective performance in activity or range of activities. ${ }^{9}$ (Pelatihan adalah proses terencana untuk mengubah sikap/prilaku, pengetahuan dan keterampilan melalui pengalaman belajar untuk mencapai kinerja yang efektif dalam sebuah kegiatan atau sejumlah kegiatan).

Undang-Undang Nomor 5 Tahun 2014 tentang Aparatur Sipil Negara mengatur tentang pengembangan kompetensi pegawai melalui pendidikan dan pelatihan. Pada Pasal 70 disebutkan bahwa setiap pegawai Aparatur Sipil Negara (ASN) memiliki hak dan kesempatan untuk mengembangkan kompetensi. Pengembangan kompetensi tersebut diantaranya melalui pendidikan dan pelatihan. Pada masa orientasi atau percobaan Pegawai negeri Sipil, proses pendidikan dan pelatihan terintegrasi untuk membangun integritas moral dan kejujuran, semangat dan motivasi nasionalisme dan kebangsaan, karakter kepribadian yang unggul dan bertanggung jawab dan memperkuat profesionalisme serta kompetensi bidang.

Untuk mengembangan kompetensi ASN setiap instansi pemerintah wajib menyusun rencana pengembangan kompetensi dalam rencana kerja anggaran tahunan dalam rangka pengembangan karir khususnya PNS. Pengembangan karier PNS nantinya harus mempertimbangkan kompetensi sebagai berikut:

8 http://harianggoro.mhs.narotama.ac.id/2012/06/19/pengembangan-karier-pns-pegawainegri-sipil/, diunduh pada hari selasa, 5 April 2016, pukul 12.00 WIB.

9 Andrew Smith, Training and Development In Australia. Second Edition, Reed International Books Australia Pty Buuterworths. Australia, 2000, hlm 2. 
1. Kompetensi teknis yang diukur dari tingkat dan spesialisasi pendidikan, pelatihan teknis fungsional dan pengalaman bekerja sebcara teknis.

2. Kompetensi manajerial yang diukur dari tingkat pendidikan, pelatihan struktural atau manajemen, dan pengalaman kepemimpianan.

3. Kompetensi sosial kultural yang diukur dari pengalaman kerja berkaitan dengan masyarakat majemuk dalam hal agama, suku, dan budaya sehingga memiliki wawasan kebangsaan.

Dengan berlakunya UU nomor 5 Tahun 2014 tentang ASN ini secara filosofis tentu saja berbeda karena memberlakukan sistem merit. Dalam merit system yang dilihat adalah kompetensi kemudian kualifikasi dan pada akhirnya kompetisi. Jadi kita ingin menghilangkan dalam system kepegawaian ini yang tadinya dari administrasi kepegawaian menjadi manajemen kepegawaian. Terus yang tadinya PNS ini masuk dalam comfort zone menjadi competitive zone. Oleh karena itu, jika dilihat dari sistem manajemen ASN ini setidaknya ada sebelas yang perlu direform. Dari mulai rekrutmen kemudian pengembangan pegawai, kemudian dari sesi promosi/karir, terus dari sisi kesejahteraan, dan sebagainya. Jadi saat ini, pertama PNS dituntut kinerjanya, kedua adalah ada sistem kompetisi, apabila memasuki jabatan penting melalui open career. Jadi kalau sampai jabatan administrasi itu adalah close career kalau mau masuk ke jabatan yang tinggi itu open career. ${ }^{10}$

Pendidikan dan pelatihan PNS yang selanjutnya disebut DIKLAT adalah proses penyelenggaraan belajar mengajar dalam rangka meningkatkan kemampuan Pegawai Negeri Sipil. Diklat Bertujuan:

1. Meningkatkan pengetahuan, keahlian, keterampilan, dan sikap untuk dapat melaksanakan tugas jabatan secara profesional dengan dilandasi kepribadian dan etika PNS sesuai dengan kebutuhan instansi;

2. Menciptakan aparatur yang mampu berperan sebagai pembaharu dan perekat persatuan dan kesatuan;

3. Memantapkan sikap dan semangat pengabdian yang berorientasi pada pelayanan, pengayoman, dan pemberdayaan masyarakat;

10 Setiawan Wangsaatmadja, SIMPUL Perencana / Volume 22 / Tahun 11 / Juli 2014, hlm.9. 
4. Menciptakan kesamaan visi dan dinamika pola pikir dalam melaksanakan tugas pemerintahan umum dan pembangunan demi terwujudnya kepemerintahan yang baik.

Sasaran Diklat adalah terwujudnya PNS yang memiliki kompetensi yang sesuai dengan persyaratan jabatan masing-masing. Jenis dan Jenjang DIKLAT adalah sebagai beikut: Diklat Prajabatan merupakan syarat pengangkatan CPNS menjadi PNS Diklat Prajabatan terdiri dari :

a. Diklat Prajabatan Golongan I untuk menjadi PNS Golongan I

b. Diklat Prajabatan Golongan II untuk menjadi PNS Golongan II.

c. Diklat Prajabatan Golongan III untuk menjadi PNS Golongan III.

Calon Pegawai Negeri Sipil (CPNS) wajib disertakan dalam diklat Prajabatan selambat-lambatnya 2 (dua) tahun setelah pengangkatannya sebagai CPNS. CPNS wajib mengikuti dan lulus Diklat prajabatan untuk diangkat sebagai PNS, Diklat Prajabatan dilaksanakan untuk memberikan pengetahuan dalam rangka pembentukan wawasan kebangsaan, kepribadian dan etika PNS disamping pengetahuan dasar tentang sistem penyelenggaraan pemerintahan negara, bidang tugas, dan budaya organisasinya agar mampu melaksanakan tugas dan perannya sebagai pelayan masyarakat.

Pesera diklat Prajabatan adalah semua Calon Pegawai Negeri Sipil (CPNS) Diklat Dalam Jabatan. Diklat dalam jabatan dilaksanakan untuk mengembangkan pengetahuan, keterampilan, dan sikap PNS agar dapat melaksanakan tugas-tugas pemerintahan dan pembangunan dengan sebaikbaiknya. Diklat Dalam Jabatan terdiri dari:

1. Diklat Kepemimpinan;

2. Diklat Fungsional;

3. Diklat Teknis.

Diklat Kepimpinan yang selanjutnya disebut Diklatpim dilaksanakan untuk mencapai persyaratan kompetensi kepemimpinan aparatur pemerintah yang sesuai dengan jenjang jabatan struktural. Diklatpim terdiri dari:

a. Diklatpim Tingkat IV adalah Diklatpim untuk Jabatan (Struktural Eselon IV); 
b. Diklatpim Tingkat III adalah Diklatpim untuk Jabatan (Struktural Eselon III);

c. Diklatpim Tingkat II adalah Diklatpim untuk Jabatan (Struktural Eselon II);

d. Diklatpim Tingkat I adalah Diklatpim untuk Jabatan (Struktural Eselon I).

Diklat Fungsional dilaksanakan untuk mencapai persyaratan kompetensi yang sesuai dengan jenis dan jenjang Jabatan Fungsional masing-masing. Jenis dan jenjang Diklat Fungsional untuk masing-masing jabatan fungsional ditetapkan oleh instansi Pembina Jabatan Fungsional yang bersangkutan.

Diklat Teknis dilaksanakan untuk mencapai persyaratan kompetensi teknis yang diperlukan untuk melaksanakan tugas PNS. Diklat Teknis dapat dilaksanakan secara berjenjang. Jenis dan Jenjang Diklat Teknis ditetapkan oleh instansi teknis yang bersangkutan.

Diklat merupakan bagian integral dan sistem pembinaan PNS, Diklat mempunyai keterkaitan dengan pengembangan karier PNS, Sistem Diklat meliputi proses identifikasi kebutuhan, perencanaan, penyelenggaraan, dan evaluasi, Diklat diarahkan untuk menyiapkan PNS agar memenuhi persyaratan jabatan yang ditentukan dalam kebutuhan organisasi termasuk pengadaan kader pimpinan dan staf. Diklat aparatur pemerintah ini meliputi dua fungsi yaitu fungsi pendidikan dan fungsi pelatihan yang merupakan satu kesatuan yang tak terpisahkan.

Dalam konteks ini Lembaga Administrasi Negara (LAN) mempunyai peranan yang sangat penting didalam menyiapkan program-program pelatihan di tingkat nasional serta melakukan supervisi, bersama Kementerian terkait yang relevan terutama Diklatpim Tingkat IV dan Tingkat III.

Manfaat diadakannya program Diklat menjadi dua, yaitu:

1. Manfaat bagi perusahaan atau instansi meliputi : Peningkatan produktivitas kerja organisasi sebagai keseluruhan antara lain karena tidak terjadinya pemborosan, karena kecermatan melaksanakan tugas, tumbuh suburnya kerjasama antara berbagai satuan kerja yang melaksanakan kegiatan yang 
berbeda dan bukan spesialistik, meningkatkan tekad mencapai sasaran yang telah ditetapkankan serta lancarnya koordinasi sehingga organisasai bergerak sebagai satu kesatuan yang utuh; Terwujudnya hubungan yang serasi antara atasan dan bawahan antara lain karena adanya pendelegasian wewenang, interaksi yang didasarkan pada sikap dewasa baik secara teknik maupun intelektual, saling menghargai, dan adanya kesepatan bagi bawahan untuk berpikir dan bertindak secara inovatif; Terjadinya proses pengambilan keputusan yang lebih cepat dan tepat karena melibatkan seluruh pegawai yang bertanggungjawab menyelenggarakan kegiatankegiatan operasional dan tidak sekedar diperintahkan oleh para manajer; Meningkatkan kesempatan kerja seluruh tenaga kerja dalam organisasi dalam komitmen organisasional yang lebih tinggi; Mendorong sikap keterbukaan manajemen melalui penerapan gaya manajerial partisipatif; Memperlancar jalannya komunikasi yang efektif yang pada gilirannya memperlancar proses perumusan kebijaksanaan organisasi dan operasionalnya; Penyelesaian konflik secara fungsional yang dampaknya adalah tumbuh suburnya rasa persatuan dan suasana kekeluargaan dikalangan anggotaorganisasi.

2. Manfaat bagi para pegawai seperti : Membantu pegawai membuat keputusan lebih baik; Meningkatkan kemampuan para pekerja menyelesaikan berbagai masalah yang dihadapi; Terjadinya internalisasi dan operasionalisasi faktor-faktor motivasi; Timbulnya dorongan dalam diri para pekerja untuk terus meningkatkan kemampuan kerjanya; Peningkatan kemampuan pegawai untuk mengatasi stres, prustrasi dan konflik yang nantinya bisa memperbesar rasa percaya pada diri sendiri; Tersedianya informasi tentang berbagai program yang dapat dimanfaatkan oleh para pegawai dalam rangka pertumbuhan masingmasing secara teknik maupun intelektual; Meningkatnya kepuasan kerja; Semakin besarnya pengakuan atas kemampuan seseorang; Semakin besarnya tekad pekerja untuk lebih mandiri; Mengurangi ketakutan menghadapi tugas baru dimasa depan. 
Mengacu pada uraian di atas dapat simpulkan bahwa manfaat yang dapat dipetik dari pelaksanaan program Diklat adalah bermanfaat untuk individu dan juga bermanfaat bagi organisasi untuk mencapai tujuan, karena peningkatan kualitas pegawai bermanfaat juga kepada peningkatan kinerja organisasi secara keseluruhan. $^{11}$

Pemerintah telah menerbitkan Instruksi Presiden (Inpres) Nomor 11 Tahun 2011 tentang Pelaksanaan Komitmen Cetak Biru MEA dalam upaya persiapan menghadapi pasar bebas ASEAN. Dalam cetak biru MEA, terdapat 12 sektor prioritas yang akan diintegrasikan oleh pemerintah. Sektor tersebut terdiri dari tujuh sektor barang yaitu industri agro, otomotif, elektronik, perikanan, industri berbasis karet, industri berbasis kayu, dan tekstil. Kemudian sisanya berasal dari lima sektor jasa yaitu transportasi udara, kesehatan, pariwisata, logistik, dan teknologi informasi. Sektor-sektor tersebut pada era MEA akan terimplementasi dalam bentuk pembebasan arus barang, jasa, investasi, dan tenaga kerja. Salah satu jalan untuk meningkatkan kualitas SDM adalah melalui jalur pendidikan. ${ }^{12}$

\section{PENUTUP.}

Berdasarkan uraian di atas, penulis menarik kesimpulan bahwa manajemen pegawai negeri sipil yang berdasarkan sistem merit sangat tepat dilaksanakan di Indonesia sebagai upaya meningkatkan kompetensi pegawai negeri sipil dalam menghadapi MEA. Selanjutnya salah satu bentuk upaya dalam meningkatkan kompetensi pegawai negeri sipil adalah dengan diikutsertakan dalam program pendidikan dan pelatihan.

11 Abdullah Tuasikal, Tujuan dan Manfaat Pendidikan dan Pelatihan (Diklat), http://www.tribunmaluku.com/2014/02/tujuan-dan-manfaat-pendidikan-dan.html, diunduh pada hari Selasa, 5 April 2016, pukul 12.00 WIB.

12 Bappenas RI, Buku I, 2011, hlm. 36. 


\section{DAFTAR PUSTAKA}

\section{A. Buku.}

Andrew Smith, Training and Development In Australia. Second Edition, Reed International Books Australia Pty Buuterworths. Australia, 2000.

Buchari Zainun, Manajemen dan Motivasi, Ghalia, Jakarta, 1986.

Inu Kencana Syafiie, Sistem Administrasi Negara Republik Indonesia (SANRI), CEt ketiga, Bimi Aksara, Jakarta, 2008.

Simanjuntak, Pengantar Ekonomi Sumber Daya Manusia, Lembaga Penerbit FEUI, Jakarta,1985.

Sri Hartini, dkk, Hukum Kepegawaian di Indonesia,Jakarta, 2010.

\section{B. Peraturan Perundang-Undangan.}

Undang-Undang Dasar 1945.

Undang-Undang Nomor 5 Tahun 2014 tentang Aparatur Sipil nasional.

\section{Internet, Jurnal, Koran.}

Abdullah Tuasikal, Tujuan dan Manfaat Pendidikan dan Pelatihan (Diklat),http://www.tribun-aluku.com/2014/02/tujuan-dan-manfaatpendidikan-dan.html, diunduh pada hari Selasa, 5 April 2016, pukul 12.00 WIB.

Bappenas RI, Buku I, 2011.

Firdaus Hafid, Pengembangan Kompetensi PNS Melalui Pendidikan danPelatihan, http://makassar.lan.go.id/index.php/survei/publikasi/artikel/2 69-pengembangan-kompetensi-pegawai-negeri-sipil-melalui-pendidikandan-pelatihan, diunduh pada hari Selasa tanggal 5 April 2016, pukul 12.00 WIB.

http://harianggoro.mhs.narotama.ac.id/2012/06/19/pengembangan-karier-pnspegawai-negri-sipil/, diunduh pada hari selasa, 5 April 2016, pukul 12.00 WIB.

LAN,http://economy.okezone.com/read/2016/04/07/320/1356886/posturbirokrasi-indonesia- hadapi-tantangan-mea, diunduh pada hari Rabu, 30 maret 2016, pukul 12.00 WIB. 
Setiawan Wangsaatmadja, SIMPUL Perencana, Volume 22, Tahun 11, Juli 2014. 